\title{
Botany
}

American Journal of Botany 100(10): 1957-1968. 2013.

\section{ENVIRONMENTAL AND GENETIC VARIATION IN LEAF ANATOMY among Populations of Andropogon gerardi (PoACEAe) ALONG A PRECIPITATION GRADIENT ${ }^{1}$}

\author{
Jacob T. Olsen ${ }^{2}$, Keri L. Caudle ${ }^{2}$, Loretta C. Johnson ${ }^{3}$, Sara G. Baer ${ }^{4}$, \\ AND BRIAN R. MARICLE ${ }^{2,5}$
}

\begin{abstract}
${ }^{2}$ Department of Biological Sciences, Fort Hays State University, 600 Park Street, Hays, Kansas 67601, USA; ${ }^{3}$ Division of Biology, Kansas State University, Manhattan, Kansas 66506, USA; and ${ }^{4}$ Department of Plant Biology and Center for Ecology,
\end{abstract} Southern Illinois University, Carbondale, Illinois 62901, USA

- Premise of the study: Phenotypes of two Andropogon gerardii subspecies, big bluestem and sand bluestem, vary throughout the prairie ecosystem of North America. This study sought to determine the role of genetics and environment in driving adaptive variation of leaf structure in big bluestem and sand bluestem.

- Methods: Four populations of big bluestem and one population of sand bluestem were planted in common gardens at four sites across a precipitation gradient from western Kansas to southern Illinois. Internal leaf structure and trichome density of $A$. gerardii were examined by light microscopy to separate genetic and environmentally controlled traits. Leaf thickness, midrib thickness, bulliform cells, interveinal distance, vein size, and trichome density were quantified.

- Key results: At all planting sites, sand bluestem and the xeric population of A. gerardii had thicker leaves and fewer bulliform cells compared with mesic populations. Environment and genetic source population were both influential for leaf anatomy. Leaves from plants grown in mesic sites (Carbondale, Illinois and Manhattan, Kansas) had thicker midribs, larger veins, fewer trichomes, and a greater proportion of bulliform cells compared to plants grown in drier sites (Colby and Hays, Kansas).

- Conclusions: Water availability has driven adaptive variation in leaf structure in populations of A. gerardii, particularly between sand bluestem and big bluestem. Genetically based differences in leaves of $A$. gerardii indicate adaptive variation and evolutionary forces differentiating sand bluestem from big bluestem. Environmental responses of A. gerardii leaves suggest an ability to adjust to drought, even in populations adapted to mesic home environments.

Key words: adaptive variation; Andropogon gerardii; big bluestem; bulliform cells; drought adaptation; ecotypes; Kranz anatomy; leaf structure; population; sand bluestem.

The environment can drive genetic changes between populations (Etterson, 2004). In plants, leaf anatomy might provide insight to assess adaptive variation and ultimately, evolutionary change (Stace, 1991). Whereas variation in general leaf anatomy has been documented between many grass species (e.g., Brown, 1958; Brown et al., 1985; Garnier and Laurent, 1994; Garnier et al., 1999; Maricle et al., 2009), anatomical variation and adaptations of leaves among populations of a single species has received little attention. Intraspecific leaf variation has been described within grasses, including reports of chloroplast structure (Zheng et al., 2000), vascular bundle area (Chen et al., 2006), mesophyll area, epidermal cell length (Ferris et al., 1996), bundle sheath area (Liu et al., 2012), midrib succulence, and stomatal density (Ferris et al., 1996; Hameed et al., 2009). Stace

\footnotetext{
${ }^{1}$ Manuscript received 6 December 2012; revision accepted 25 June 2013. This work was supported by the U. S. Department of Agriculture, National Institute of Food and Agriculture (grant no. 2008-35100-04545), the FHSU Department of Biological Sciences, the College of Health and Life Sciences Thomson Trust, the Kansas Native Plant Society, the Grassland Heritage Foundation, and the Li-Cor LEEF program. The authors thank $\mathrm{H}$. Tetreault for assistance with collecting leaves, J. Thomasson for advice on specimen preparation, M. Knapp for help with climate data, and the Kansas State Agricultural Research Centers at Hays and Colby, the USDA Plant Material Center in Manhattan, and the SIU Agronomy Research Center for site maintenance.

${ }^{5}$ Author for correspondence (e-mail: brmaricle@fhsu.edu)
}

(1991) suggested anatomical features in grasses might be more important than morphological features systematically because anatomical features are less susceptible to environmental change. As such, variation in leaf anatomy might be useful in assessing strong environmental influences on plants as well as potentially illustrating genetically based structural differences during incipient speciation.

Common garden experiments are frequently used to determine whether characteristics of a population are influenced by genetic or environmental factors (Clausen et al., 1948; Bresson et al., 2011). Leaf anatomy has been studied in common gardens over climatic gradients (Cordell et al., 1998; Hovenden and Schoor, 2004), and variation has often been attributed to environmental factors (Scheiner and Goodnight, 1984). For example, leaf form and function can differ greatly under high and low light conditions (Jiang et al., 2011). Furthermore, altitudinal variation in temperature, partial pressure of $\mathrm{CO}_{2}$, and irradiance can affect leaf size (Williams and Black, 1993), stomatal density, and leaf thickness (Körner et al., 1986; Cordell et al., 1998). Much published work indicates environment plays the primary role in shaping leaf anatomy of populations within a species (Smith and Nobel, 1978; Hovenden and Schoor, 2004; Carmo-Silva et al., 2009), showing the plasticity of leaf anatomy. However, natural selection could also shape leaf structure in populations adapted to clinal variation in climate, especially precipitation.

Anatomical variation is expected within and among populations in response to water availability (e.g., Chen et al., 2006), 
and $\mathrm{C}_{4}$ grasses provide numerous anatomical characteristics of interest. $\mathrm{C}_{4}$ grass leaves have Kranz anatomy, characterized by enlarged bundle sheath cells containing chloroplasts rich in starch (Dengler et al., 1994; Muhaidat et al., 2007). In addition, few mesophyll cells separate the closely arranged vascular bundles of $\mathrm{C}_{4}$ grasses (Sudderth et al., 2007). Many aspects of leaf anatomy and leaf responses demonstrate $\mathrm{C}_{4}$ grasses are well adapted to xeric environments. Leaf rolling is common in drought tolerant grasses (Kadioglu et al., 2012). Specialized epidermal cells, called bulliform cells, facilitate leaf rolling or folding by decreased turgor pressure as plant water potential decreases (Barnes, 1985, 1986; Maricle et al., 2009; Kadioglu et al., 2012). In addition, leaf trichomes are often an adaptation for water conservation (Liu et al., 2012) as they can reduce incoming radiation (Galmés et al., 2007) or increase boundary layer resistance to water loss (Pérez-Estrada et al., 2000), either of which could be an adaptation in xeric grasses.

The prairie ecosystem of North America contains a precipitation gradient, ranging from $50 \mathrm{~cm}$ annually in the west to more than $120 \mathrm{~cm}$ annually in the east (Sala et al., 1988; Epstein et al., 1998), which has been a selective force for the last $20000 \mathrm{yr}$ (Axelrod, 1985). Andropogon gerardii Vitman (big bluestem) is a dominant prairie grass (Epstein et al., 1998; Knapp et al., 1998) that has been shown to exhibit phenotypic variation among populations occurring along the latitudinal gradient of the Great Plains (McMillan, 1959). Most notably, A. gerardii subsp. hallii $(=A$. hallii; sand bluestem), which is restricted to sand dunes and sandy soils, might represent a separate species or a subspecies in the process of edaphic speciation (Newell and Peters, 1961; Barnes, 1985, 1986; Barkworth et al., 2007). Determining the relevant structural differences between subspecies and assessing the degree to which these features are genetically or environmentally influenced is of great interest in evolutionary biology. Results of such studies might also provide insight into how adjustable structural anatomical features are to current and future climate (Shaw and Etterson, 2012).

Drought is a prominent environmental stress that influences leaf structure (Smith and Nobel, 1978; Carmo-Silva et al., 2009); when populations within a species are compared, structure can provide insight on evolutionary change during incipient speciation. We investigated leaf anatomy of $A$. gerardii to elucidate environmental and genetic controls of variation in leaf characteristics in response to the precipitation gradient of the Great Plains, a gradient that has been in place sufficiently long for selection to act. Leaves of five populations of $A$. gerardii, including sand bluestem, were sampled from four common gardens established across a climate gradient and evaluated by light microscopy. Because of conspicuous phenotypic differences, populations were expected to have differences under genetic control in leaf thickness and internal structure, in addition to environmentally controlled phenotypic variation.

Anatomical and morphological differences have been documented among populations of a single grass species grown at a common site (e.g., McWhorter, 1971; Barnes, 1986) and accordingly, we expected leaf anatomy of A. gerardii source populations to vary when grown at common sites. We hypothesized: (1) the population source of $A$. gerardii originating from central KS would exhibit drought-adapted traits to a greater extent compared to more mesic populations (originating in eastern $\mathrm{KS}$ and southern IL) by containing a higher percentage of bulliform cells for leaf rolling or folding; (2) all A. gerardii populations would have a higher percentage of bulliform cells when grown at dry sites in Colby, Kansas (KS) and Hays, KS compared to wetter sites in Manhattan, KS and Carbondale, Illinois (IL); (3) plants grown at mesic common garden sites (Manhattan and Carbondale) would have larger veins and a greater proportion of the leaf would consist of veins than at the drier common garden sites (Colby and Hays); (4) leaves of A. gerardii originating from central KS would be thicker than the more mesic populations; (5) trichome density would increase in plants grown under more arid conditions; and (6) environment would influence leaf anatomy of populations more than genetically based differences in source populations.

\section{MATERIALS AND METHODS}

Seed collection and planting of common gardens-Individuals of five populations of $A$. gerardii were planted in four common gardens along the west-east climate gradient of the Great Plains as part of a large common garden experiment. Seeds for three A. gerardii populations were hand collected in 2008 from Cedar Bluff Reservoir in western Kansas, USA ( $\left.38^{\circ} 45^{\prime} \mathrm{N}, 99^{\circ} 46^{\prime} \mathrm{W}\right)$, Konza Prairie in eastern Kansas, USA ( $39^{\circ} 05^{\prime}$ N, $96^{\circ} 36^{\prime}$ W), and Twelve Mile Prairie in southern Illinois, USA $\left(38^{\circ} 46^{\prime} \mathrm{N}, 88^{\circ} 50^{\prime} \mathrm{W}\right)$ (Fig. 1). Seeds of two widely used cultivars, A. gerardii 'Kaw' (big bluestem accession 421276) and A. gerardii var. hallii 'Garden' (sand bluestem accession 421277), were obtained from the USDA Manhattan Plant Materials Center in Manhattan, KS, USA. Throughout this paper, the Cedar Bluff population is referred to as a xeric population and the Konza and 12 Mile populations are referred to as mesic populations.

In autumn 2008, seeds from each population of $A$. gerardii were planted in Metromix 510 potting mix (Scotts Co., Marysville, Ohio, USA) in $10 \times 10 \mathrm{~cm}$ pots in a greenhouse at Kansas State University. In August 2009, A. gerardii plants were transplanted from pots into four common experimental gardens in Colby, Hays, and Manhattan, KS, and Carbondale, IL, following a precipitation gradient ranging from $50 \mathrm{~cm}$ annually in Colby, KS to $117 \mathrm{~cm}$ annually in Carbondale, IL (Table 1, Fig. 1). Common gardens were within $230 \mathrm{~km}$ of each of the three collection sites; thus, climatic data from the common garden sites (Table 1) also represent seed collection sites. A westernmost common garden was also included in Colby, KS at the edge of the distribution of A. gerardii to investigate effects of drier climate on leaf anatomy. All five populations of big bluestem were planted at each common garden. Plants were arranged $50 \mathrm{~cm}$ apart and were surrounded by landscape fabric to decrease competition from unwanted plants. Common gardens were arranged in 10 rows with one plant of each population in each row, totaling 10 plants of each population at each common garden site. Common gardens were unshaded, and plants grew under ambient conditions at each site. Soil moisture was monitored with four EC-20 soil moisture probes, $20 \mathrm{~cm}$ in length (Decagon Devices, Pullman, Washington, USA), arranged diagonally across each site (Table 1). Precipitation data were gathered from local research stations and historical records (Table 1).

Collecting and fixing of leaf and culm tissue-In the middle of the 2010 growing season, one leaf from each of three randomly selected plants from each population was sampled at each common garden site, totaling 60 leaves ( 3 replicates per population $\times 5$ populations $\times 4$ common garden sites). Leaves were collected more than 1 year after planting, thus minimizing maternal effects (Schmid and Dolt, 1994). There was a prominent difference in plant size across sites, illustrating a strong environmental influence on plants. Average plant height in Colby, KS was near $60 \mathrm{~cm}$ during sampling (with many tillers per plant), and average plant height in Carbondale, IL was greater than $2.0 \mathrm{~m}$ at the same time, but with fewer tillers (L. C. Johnson et al., unpublished manuscript). Plants in Hays, KS and Manhattan, KS were intermediate in height and tiller production. During sampling, the middle portion of the youngest, fully expanded leaf was taken from these plants. In addition, 8-10 cm segments of culm were collected for trichome analysis. Culm segments contained stem and one or more nodes and leaf bases. Samples were collected from each of three randomly selected plants of each population at each common garden site, totaling $60 \mathrm{culm}$ segments that were separate from samples for leaf anatomy. Leaves and culm segments were fixed in FAA (10\% formalin, 50\% ethanol, 5\% glacial acetic acid, $35 \% \mathrm{dH}_{2} \mathrm{O}$, v/v) and stored at $4{ }^{\circ} \mathrm{C}$.

Sample preparation for leaf cross sections-Leaves were washed for $1 \mathrm{~h}$ with $50 \%$ ethanol and then dehydrated and infiltrated with paraffin over a series of ethanol and tert-butyl alcohol solutions according to Ruzin (1999), 


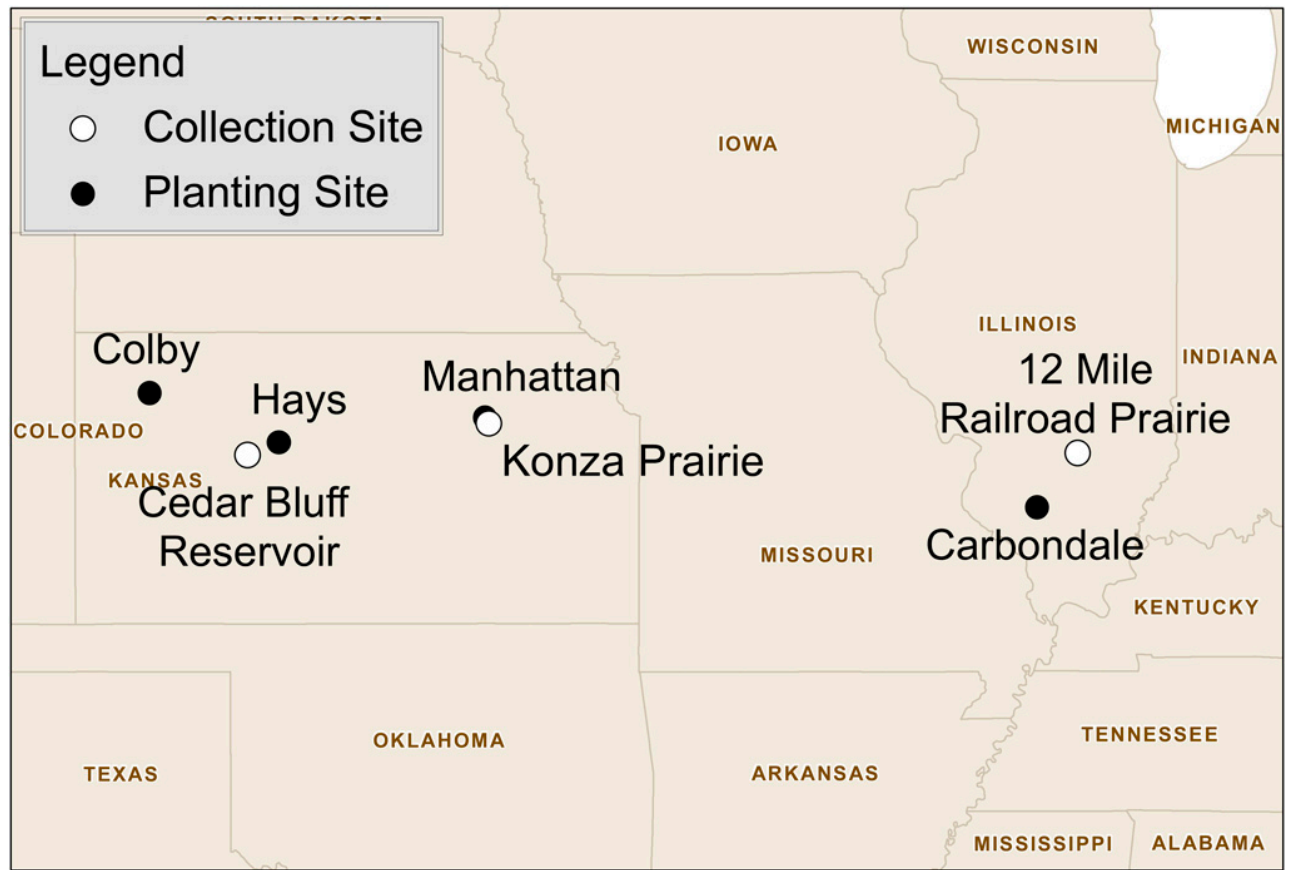

Fig. 1. Map showing seed collection sites (open circles) and common garden sites (filled circles) for Andropogon gerardii populations.

with a minimum of 30 min per solution. A final step was added with $33 \%$ tert-butyl alcohol and 67\% paraffin oil. Leaves were embedded in Carowax (Carolina Biological Supply, Burlington, North Carolina, USA) by melting the wax at $58^{\circ} \mathrm{C}$ and immersing leaves into melted wax for a minimum of $12 \mathrm{~h}$.

Embedded leaves were sectioned at thicknesses from 10-20 $\mu \mathrm{m}$ with a Spencer Model 815 Microtome (American Optical, Buffalo, New York, USA) to find the optimal thickness for each leaf. Glass slides were prepared by smearing a drop of Haupt's adhesive uniformly over the surface of the slide and then flooding the surface with $4 \%$ aqueous formaldehyde. Microtome ribbons were placed on the flooded slide and the slide was placed on a warming tray at $37^{\circ} \mathrm{C}$ for a minimum of $10 \mathrm{~min}$, then removed and stored horizontally overnight. Leaf sections underwent a xylene-alcohol series to dewax and rehydrate. Sections were stained with $1 \%$ safranin $(\mathrm{w} / \mathrm{v}$ in $50 \%$ ethanol) and $0.05 \%$ toluidine blue (w/v in $50 \mathrm{mM}$ citrate buffer). Dehydration followed with an alcohol-xylene series.

A drop of Kleermount (Carolina Biological Supply) was placed on the processed slides and a coverslip was placed on the slide. Slides were stored horizontally overnight.

TABLE 1. Environmental conditions for the four planting sites of Andropogon gerardii populations.

\begin{tabular}{lcccc}
\hline \hline \multirow{2}{*}{$\begin{array}{l}\text { Environment } \\
\text { conditions }\end{array}$} & \multicolumn{4}{c}{ Common garden planting site } \\
\cline { 2 - 5 } Colby, KS & Hays, KS & Manhattan, KS & Carbondale, IL \\
\hline Location coordinates & $39^{\circ} 23^{\prime} \mathrm{N}$ & $38^{\circ} 51^{\prime} \mathrm{N}$ & $39^{\circ} 08^{\prime} \mathrm{N}$ & $37^{\circ} 73^{\prime} \mathrm{N}$ \\
& $101^{\circ} 04^{\prime} \mathrm{W}$ & $99^{\circ} 19^{\prime} \mathrm{W}$ & $96^{\circ} 38^{\prime} \mathrm{W}$ & $89^{\circ} 22^{\prime} \mathrm{W}$ \\
$\begin{array}{c}2010 \text { annual } \\
\text { precipitation (cm) }\end{array}$ & 44.57 & 50.11 & 67.82 & 66.95 \\
$\begin{array}{c}\text { Mean annual } \\
\text { precipitation, } \\
\text { since 1961 (cm) }\end{array}$ & 50.47 & 58.22 & 87.15 & 116.73 \\
$\begin{array}{c}\text { Average 2010 soil } \\
\text { moisture (\%) }\end{array}$ & 10.9 & 10.7 & 17.5 & 23.6 \\
$\begin{array}{c}\text { Mean potential } \\
\text { evapotranspiration } \\
\text { (PET), since } \\
\quad \text { 1961 (cm) }\end{array}$ & 144 & 139 & 127 & 99 \\
$\begin{array}{l}\text { Aridity index (cm) } \\
\quad \text { PET-ppt) }\end{array}$ & 94 & 81 & 40 & -18 \\
\begin{tabular}{l} 
Soil type \\
\hline
\end{tabular} & silt loam & silt loam & sandy loam & silt loam \\
\hline
\end{tabular}

Measurements on leaf cross sections-An Olympus BX51 microscope (Olympus, Center Valley, Pennsylvania, USA) with an attached Olympus DP71 digital camera was used to take bright field images of leaf sections. Images were analyzed with the program Image $\mathbf{J}$ (National Institutes of Health, Bethesda, Maryland, USA). Measurements on each section included maximum leaf thickness at the midrib, maximum and minimum leaf thickness at a nonmidrib area, interveinal distance, area of the minor veins and of the major veins, and proportion of each bulliform cells and vascular tissue based on cross-sectional leaf area. Interveinal distance was measured as the minimum distance between the two nearest bundle sheath cells of adjacent vascular bundles. Maximum and minimum leaf thicknesses at a nonmidrib area were measured at a minimum of $200 \mu \mathrm{m}$ from the midrib, but at least $200 \mu \mathrm{m}$ from the leaf edge. Minor and major vein areas included the vascular bundle and bundle sheath. Measurements for each leaf are the mean of six duplicate minor or major veins, averaged within the same order of veins.

Trichome analyses-Culm segments were removed from fixative, allowed to dry, and examined for trichome density at $7 \times$ under an Olympus SZX16 dissection microscope. Images were captured with an Olympus Altra 20 digital camera. Trichome density was calculated on the basal $10-15 \mathrm{~mm}$ of the lamina. The lamina portion was removed from the culm segment by cutting at the collar, where the lamina meets the sheath, and cutting away the remainder of the leaf. Length and width of the lamina portion were measured with digital calipers, and all trichomes were counted on the adaxial surface to arrive at a density in trichomes $/ \mathrm{mm}^{2}$ (Campos et al., 2009). In leaves with dense trichome cover, it was necessary to remove trichomes with a dissecting needle prior to counting. In most (35) individuals, two duplicate leaves were averaged per replicate plant. In the other 25 individuals, one leaf was measured per replicate plant.

Statistical analyses-All data were analyzed with the program JMP 9.0.2 (SAS Institute, Cary, North Carolina, USA). Replicate measures were from three plants of the same population at each site. A two-way ANOVA was used; factors were site, population, and the interaction between site and population. This analysis was followed with Tukey's honestly significant difference tests to determine significant differences between means. Statistical significance was assigned at $\alpha=0.05$.

\section{RESULTS}

Vascular tissue - Leaves from all populations and sites had Kranz anatomy (Dengler and Nelson, 1999) with two distinct 
types of photosynthetic cells and closely spaced veins (Fig. 2). Photosynthetic tissue was composed of a single layer of large chlorenchymatous bundle sheath cells encircled by one layer of chlorenchymatous mesophyll cells. Each mesophyll cell was in direct contact with a bundle sheath cell. In some cases, colorless parenchyma cells separated mesophyll cells from those of neighboring veins. Bundle sheath cells were large and contained centrifugal chloroplasts. Frequently, the bundle sheath of major veins was connected to the epidermis by a bundle sheath extension. Bundle sheath extensions were especially notable in the sand bluestem population (Fig. 2).

In all leaves, major veins contained an inner mestome sheath of sclerenchymatous cells (Fig. 2). Mestome sheaths surrounded the phloem, but not the entire vascular bundle, similar to observations by Brown (1975). In all populations except sand bluestem, bundle sheath cells on the xylem side of major veins had thick secondary walls. The most heavily lignified bundle sheath cells contained no chloroplasts. Additionally, the abaxial side of major and minor veins and the adaxial side of major veins were protected by sclerenchymatous fiber bundles, which were particularly conspicuous in the sand bluestem population (Fig. 2).

In some leaves, interveinal distances were short because mesophyll cells of neighboring vascular bundles were directly contacting each other (Fig. 3D). In other leaves, colorless parenchyma cells separated mesophyll cells of neighboring vascular bundles, increasing the interveinal distance. Interveinal distance varied from leaf to leaf (Table 2), and there were no significant effects of site $\left(F_{3,40}=0.96, P=0.422\right)$ or population $\left(F_{4,40}=1.67, P=0.176\right)$.

Cross-sectional areas of major veins differed by site because of differences in phloem and xylem cross-sectional area (Fig. 4A), often with larger sieve tubes and vessel elements at the mesic

\section{Cedar Bluff}

Konza
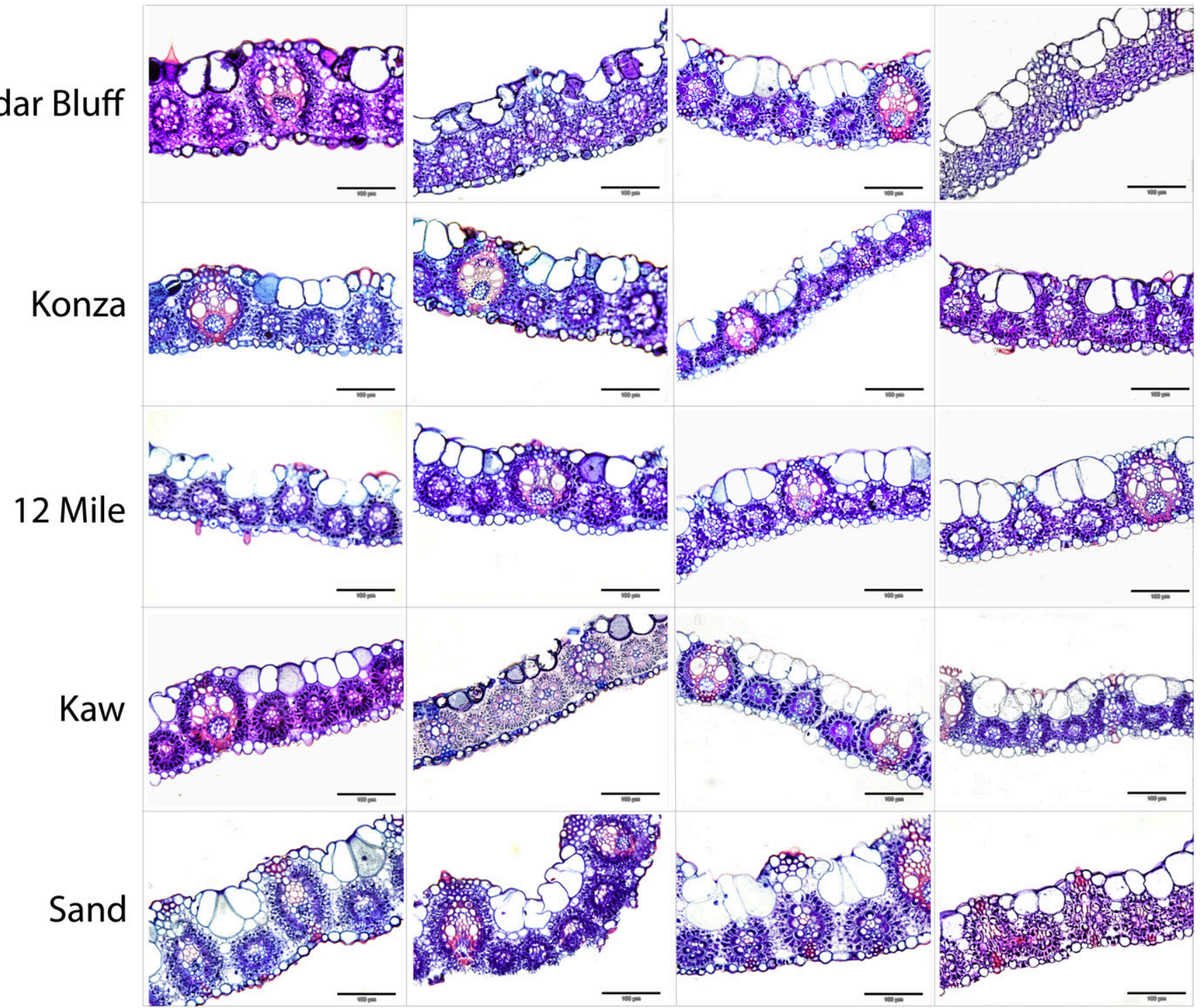

Colby

Hays

Manhattan

Carbondale

Fig. 2. Representative leaf cross sections of five populations of Andropogon gerardii leaves (rows) at each planting site (columns), arranged from most xeric site on the left to most mesic site on the right. Scale bars $=100 \mu \mathrm{m}$. 


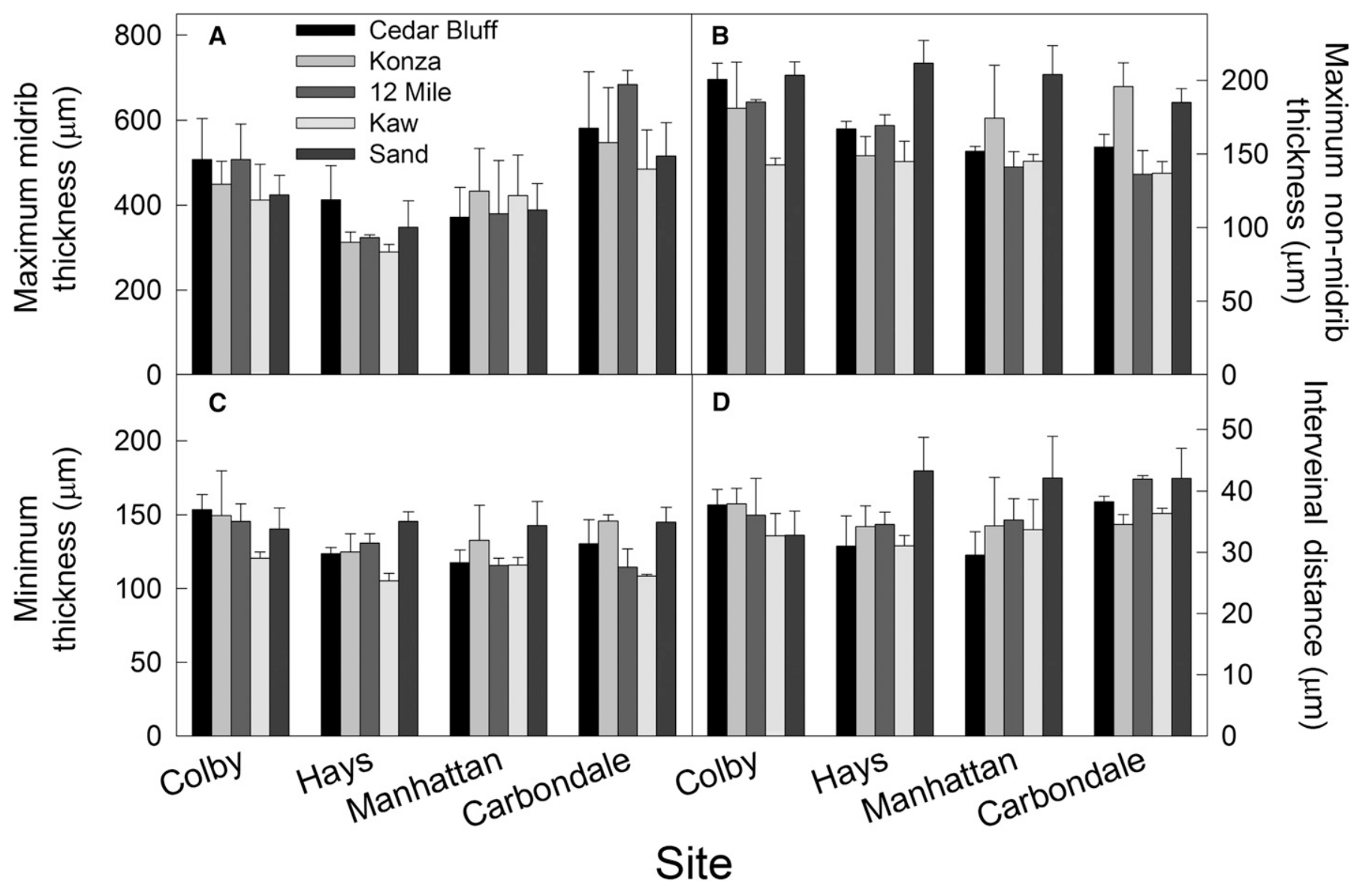

Fig. 3. (A) Maximum midrib thickness, (B) maximum leaf thickness outside of the midrib, (C) minimum leaf thickness, (D) interveinal distance, in five Andropogon gerardii populations at the four planting sites. Bars are means from three replicate leaves \pm SE. Tukey's HSD comparisons are presented in Tables 3-4.

Carbondale site compared to other sites $\left(F_{3,40}=5.18, P=0.004\right)$. In Colby, KS, major veins were not different from other sites (Table 3). No differences were detected among populations $\left(F_{4,40}=1.22, P=0.316\right)$.

Minor veins were surrounded by large chlorenchymatous bundle sheath cells with no lignification and no mestome sheath, similar to observations of Brown (1975). The crosssectional area of minor veins did not vary across sites $\left(F_{3,40}=\right.$ $0.88, P=0.462)$ or among populations $\left(F_{4,40}=1.29, P=\right.$ 0.291) (Fig. 4B).
The proportion of total leaf cross-sectional area occupied by vascular bundles was variable across sites and populations (Fig. 4D). Variation arose from abundances of bulliform cells, colorless parenchyma cells, and mesophyll cells. No differences in percentage of vascular bundles were detected across sites $\left(F_{3,40}=\right.$ $1.71, P=0.181)$. Among populations, the proportion of total leaf cross-sectional area composed of vascular bundle areas of 12 Mile and Kaw was marginally greater than in Cedar Bluff $\left(F_{4,40}=2.41, P=0.065\right)$, whereas sand bluestem and Konza were not different from other populations.

TABLE 2. Main and interactive effects of the population of Andropogon gerardii and the planting site on leaf anatomy $(\mathrm{df}$ error $=40)$ of ANOVA.

\begin{tabular}{|c|c|c|c|c|c|c|c|c|c|}
\hline \multirow[b]{2}{*}{ Character } & \multicolumn{3}{|c|}{ Population } & \multicolumn{3}{|c|}{ Site } & \multicolumn{3}{|c|}{ Population $\times$ Site } \\
\hline & df & $F$ & $P$ & df & $F$ & $P$ & df & $F$ & $P$ \\
\hline Midrib thickness & 4 & 0.57 & 0.687 & 3 & 6.89 & $<0.001$ & 12 & 0.35 & 0.972 \\
\hline Maximum thickness (nonmidrib) & 4 & 8.56 & $<0.001$ & 3 & 2.05 & 0.122 & 12 & 1.27 & 0.276 \\
\hline Minimum thickness & 4 & 3.58 & 0.014 & 3 & 1.94 & 0.138 & 12 & 0.54 & 0.875 \\
\hline Interveinal distance & 4 & 1.67 & 0.176 & 3 & 0.96 & 0.422 & 12 & 0.70 & 0.736 \\
\hline Major veins (area) & 4 & 1.22 & 0.316 & 3 & 5.18 & 0.004 & 12 & 1.04 & 0.428 \\
\hline Minor veins (area) & 4 & 1.29 & 0.291 & 3 & 0.88 & 0.462 & 12 & 0.78 & 0.670 \\
\hline$\%$ Bulliform cells & 4 & 4.73 & 0.003 & 3 & 5.23 & 0.004 & 12 & 0.70 & 0.739 \\
\hline$\%$ Vascular bundles & 4 & 2.41 & 0.065 & 3 & 1.71 & 0.181 & 12 & 0.86 & 0.593 \\
\hline Trichome density & 4 & 10.54 & $<0.001$ & 3 & 10.51 & $<0.001$ & 12 & 3.40 & 0.002 \\
\hline
\end{tabular}

Notes: Significant values $(P<0.05)$ are in bold; values close to significance are italicized. 


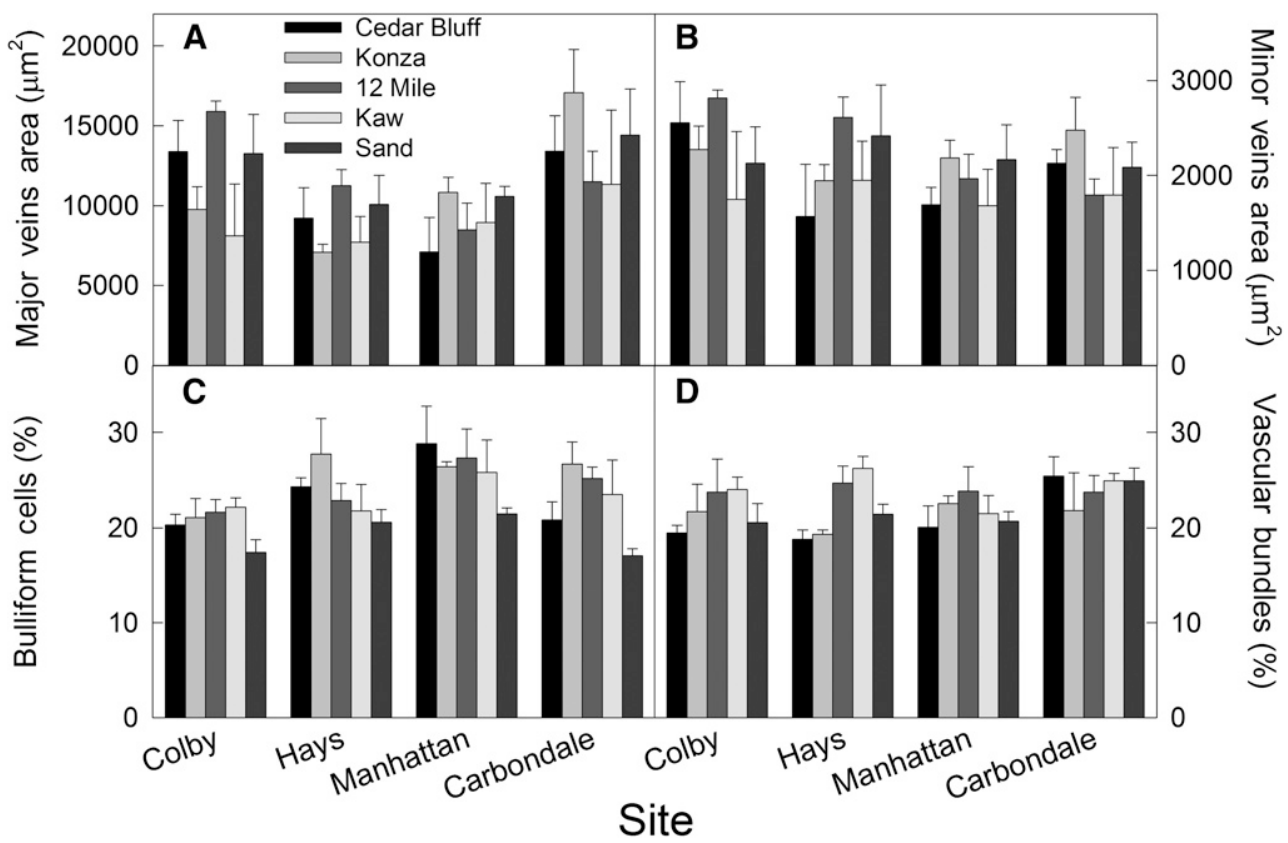

Fig. 4. (A) Cross-sectional area of major veins, (B) cross-sectional area of minor veins, (C) cross-sectional area of leaf consisting of bulliform cells, and (D) cross-sectional area of leaf consisting of vascular bundles in five Andropogon gerardii populations at the four planting sites. Bars are means from three replicate leaves \pm SE. Tukey's honestly significant difference comparisons are presented in Tables 3-4.

Bulliform cells-Bulliform cells occurred in groups of two to eight adjacent cells and occupied most of the epidermis adaxial to minor veins (Fig. 2). Bulliform cells were not present on the abaxial side of leaves. Bulliform cells were the largest cells in leaves, but differed considerably in size among populations and sites (Table 2), with larger bulliform cells at the mesic Carbondale, IL site and smaller bulliform cells at the other sites (Fig. 4C). Across sites, Colby, KS had a higher percentage of bulliform cells compared to plants at Manhattan, $\mathrm{KS}\left(F_{3,40}=\right.$ 5.23, $P=0.004$ ) (Table 3). Among populations, 12 Mile and Konza had a greater proportion of bulliform cells than did sand bluestem $\left(F_{4,40}=4.73, P=0.003\right)$ (Table 4$)$.

Midribs-Midribs consisted of large, colorless parenchyma cells on the adaxial side of leaves and chlorenchyma and vascular tissue on the abaxial side, with a large abaxial bundle of sclerenchymatous fibers protecting the midvein (Fig. 5). Midveins typically had a prominent mestome sheath. In some cases, mechanical cells lined the adaxial side of the midrib. Variation in midrib thickness was predominantly due to the number and size of colorless parenchyma cells. The abundance of colorless parenchyma cells in each midrib cross section ranged from under 20 to well over 100 cells. Variation in the size of vascular bundles and thickness of abaxial fiber bundles were minor contributions to midrib thickness. Midribs were thicker in Carbondale, IL than in Manhattan, KS or Hays, $\mathrm{KS}\left(F_{3,40}=6.89, P<0.001\right)$ (Fig. 3A) (Table 3). There were no differences among populations $\left(F_{4,40}=0.57, P=0.687\right)$.

Leaf thickness (nonmidrib)_Leaf blades retained a consistent thickness at distances from $200 \mu \mathrm{m}$ outside the midrib to $200 \mu \mathrm{m}$ inside the leaf edge (Figs. 2, 5). The majority of leaf volume consisted of vascular bundles, chlorenchyma, epidermal cells, and bulliform cells, with minor contributions from intercellular spaces and colorless parenchyma cells. Leaf thickness varied primarily due to sizes of bulliform cells and vascular bundles. Maximum leaf thickness did not differ across planting sites $\left(F_{3,40}=2.05, P=0.122\right)$ (Fig. 3B). Among populations, sand bluestem leaves were not different from Konza leaves, but were thicker than Cedar Bluff, 12 Mile, and Kaw $\left(F_{4,40}=8.56, P<0.001\right)$. Konza was not different from Cedar Bluff or 12 Mile, but was thicker than Kaw (Table 4).

Minimum leaf thickness was not different across sites $\left(F_{3,40}=\right.$ $1.94, P=0.138$ ) (Fig. 3C). Sand bluestem and Konza had minimum thicknesses greater than Kaw $\left(F_{4,40}=3.58, P=0.014\right)$, whereas Cedar Bluff and 12 Mile were not different from any other populations (Table 4).

TABLE 3. Least square means (LSM) for site results of Tukey's honestly significant difference test for area of major veins $\left(\mu \mathrm{m}^{2}\right)$, proportion of leaf consisting of bulliform cells, maximum midrib thickness $(\mu \mathrm{m})$, and trichome density $\left(\mathrm{mm}^{-2}\right)$ in leaves of Andropogon gerardii populations.

\begin{tabular}{lcccc}
\hline \hline Site & $\begin{array}{c}\text { LSM, Area of major } \\
\text { veins }\left(\mu \mathrm{m}^{2}\right)\end{array}$ & $\begin{array}{c}\text { LSM, Proportion of leaf consisting } \\
\text { of bulliform cells }\end{array}$ & $\begin{array}{c}\text { LSM, Maximum midrib } \\
\text { thickness }(\mu \mathrm{m})\end{array}$ & \begin{tabular}{c} 
LSM, Trichome density $\left(\mathrm{mm}{ }^{-2}\right)$ \\
\hline Carbondale, IL
\end{tabular} \\
Manhattan, KS & $13541^{\mathrm{A}}$ & $0.227^{\mathrm{A}, \mathrm{B}}$ & $562.5^{\mathrm{A}}$ & $0.5^{\mathrm{B}}$ \\
Hays, KS & $9188^{\mathrm{B}}$ & $0.260^{\mathrm{A}}$ & $398.8^{\mathrm{B}}$ & $1.6^{\mathrm{B}}$ \\
Colby, KS & $9062^{\mathrm{B}}$ & $0.235^{\mathrm{A}, \mathrm{B}}$ & $337.1^{\mathrm{B}}$ & $2.1^{\mathrm{B}}$ \\
\hline
\end{tabular}

Note: Sites means accompanied by the same letter were not significantly different $(\alpha=0.05)$. 
TABLE 4. Tukey's honestly significant difference test for proportion of leaf consisting of bulliform cells, maximum leaf thickness ( $\mu$ m) at a nonmidrib area, minimum leaf thickness $(\mu \mathrm{m})$ at a nonmidrib area, and trichome density $\left(\mathrm{mm}^{-2}\right)$ in Andropogon gerardii populations.

\begin{tabular}{|c|c|c|c|c|}
\hline Population & $\begin{array}{l}\text { LSM, Proportion of leaf consisting } \\
\text { of bulliform cells }\end{array}$ & $\begin{array}{l}\text { LSM, Maximum leaf thickness } \\
\qquad(\mu \mathrm{m}) \text { not at midrib }\end{array}$ & $\begin{array}{l}\text { LSM, Minimum leaf thickness } \\
\qquad(\mu \mathrm{m}) \text { not at midrib }\end{array}$ & LSM, Trichome density $\left(\mathrm{mm}^{-2}\right)$ \\
\hline 12 Mile & $0.243^{\mathrm{A}}$ & $157.9^{\text {в,C }}$ & $126.6^{\mathrm{A}, \mathrm{B}}$ & $4.1^{\mathrm{A}}$ \\
\hline Konza & $0.255^{\mathrm{A}}$ & $174.9^{\mathrm{A}, \mathrm{B}}$ & $138.2^{\mathrm{A}}$ & $3.7 \mathrm{~A}, \mathrm{~B}$ \\
\hline Kaw & $0.233^{\mathrm{A}, \mathrm{B}}$ & $142.3^{\mathrm{C}}$ & $112.5^{\text {в }}$ & $0.9^{\mathrm{C}}$ \\
\hline Sand & $0.191^{\text {в }}$ & $201.0^{\mathrm{A}}$ & $143.4^{\mathrm{A}}$ & $0.1^{\mathrm{C}}$ \\
\hline
\end{tabular}

Note: Populations means accompanied by the same letter were not significantly different $(\alpha=0.05)$.

Trichomes-Mean leaf trichome density increased as sites became more arid (Figs. 6, 7), demonstrated by plants from Colby, KS, which had a significantly greater trichome density compared with all other sites $\left(F_{3.40}=10.51, P<0.001\right)$ (Table 3$)$. Leaves from mesic Konza and 12 Mile populations had greater trichome densities compared to the xeric Cedar Bluff population, the cultivar Kaw, or sand bluestem (Table 2, Fig. 7) $\left(F_{4,40}=10.54, P<0.001\right)$. There was a significant population $\times$ site interaction $\left(F_{12,40}=3.4, P=0.002\right)$, indicating a strong increase of 12 Mile and Konza populations to increasing aridity.

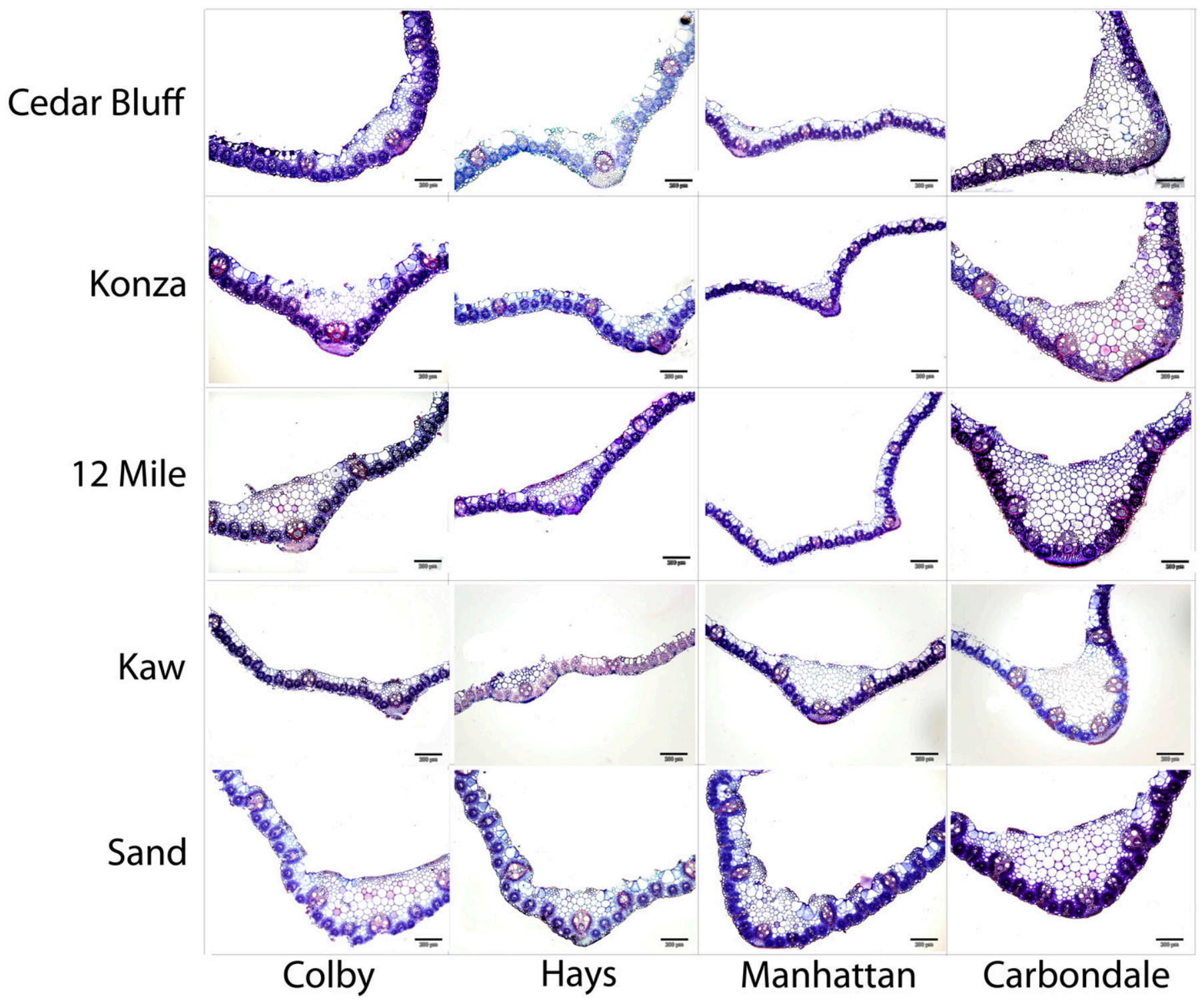

Fig. 5. Representative leaf cross sections of Andropogon gerardii leaves showing midribs of each population (rows) at each planting site (columns), arranged from most xeric site on the left to most mesic site on the right. Scale bars $=200 \mu \mathrm{m}$. 


\section{Cedar Bluff}
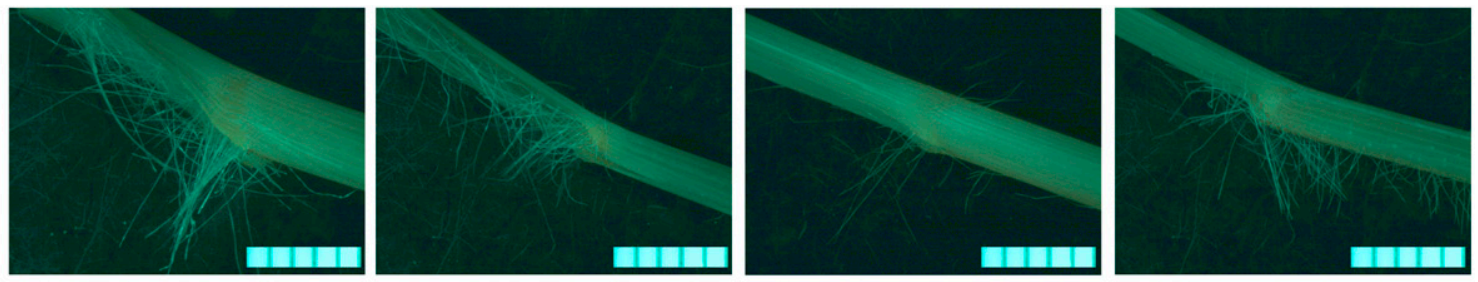

Konza
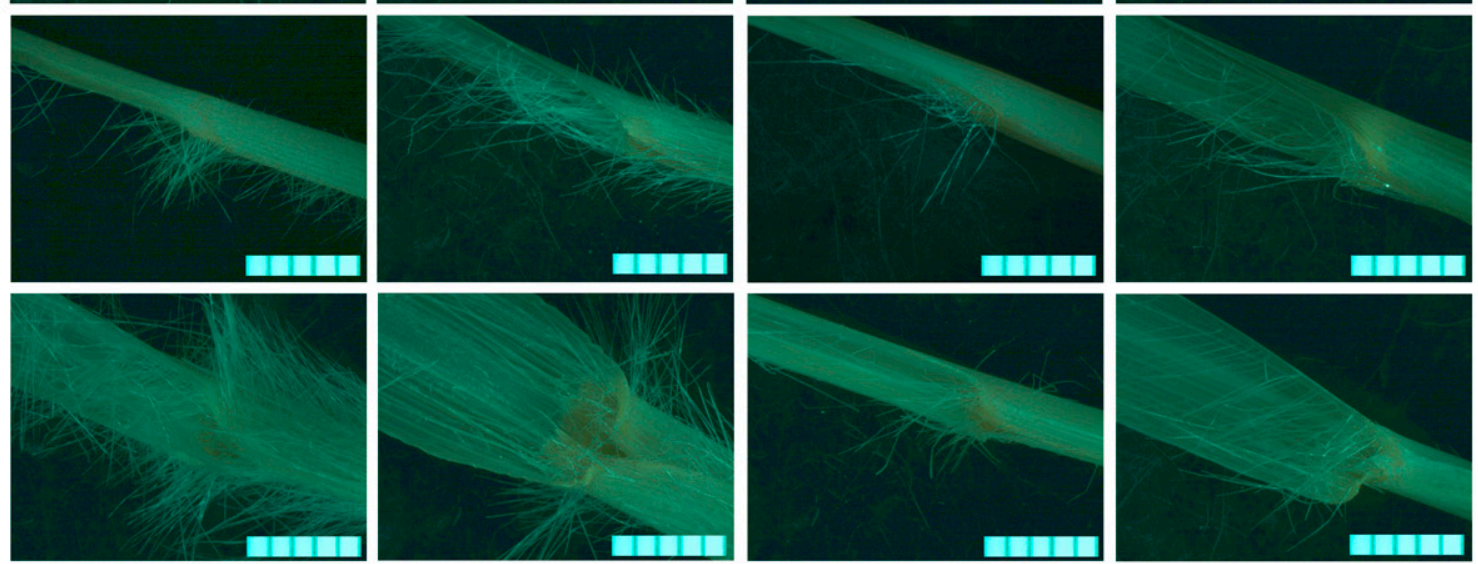

12 Mile

Kaw
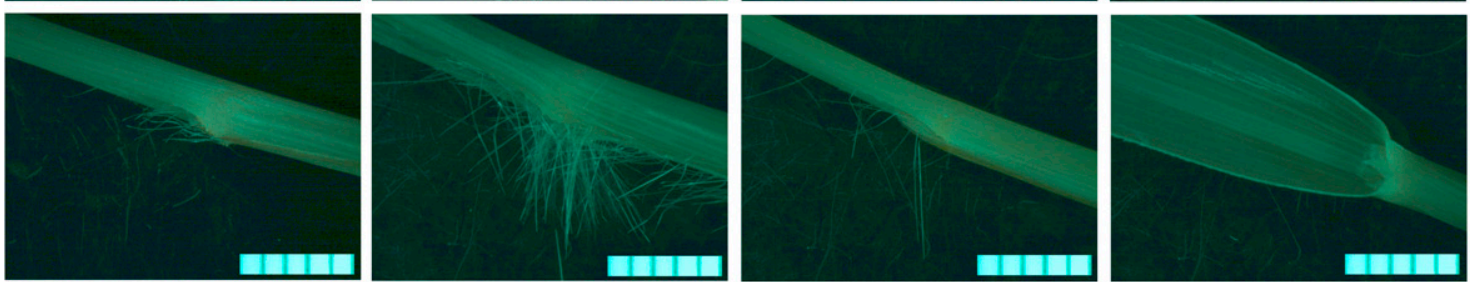

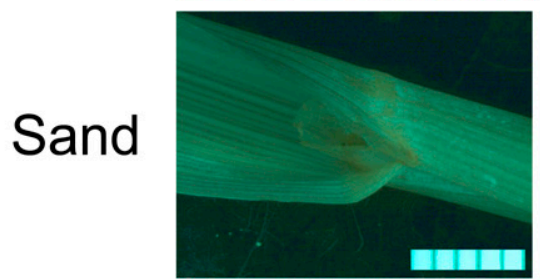

Colby

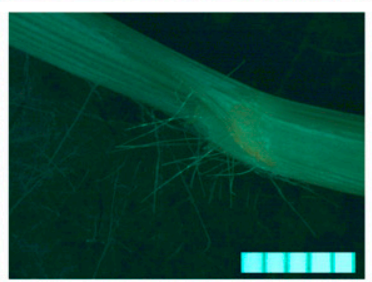

Hays

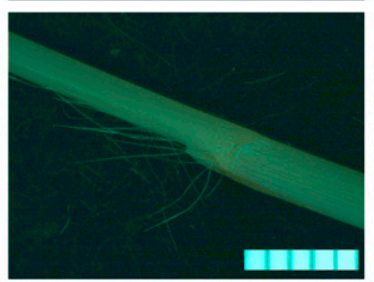

Manhattan

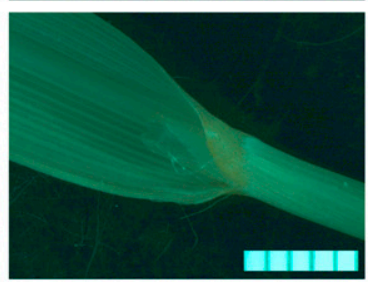

Carbondale

Fig. 6. Representative leaves of Andropogon gerardii illustrating variation of trichome density where the lamina joins the collar. Images across populations and sites are organized as in Figs. 2 and 5. Scale bars $=5 \mathrm{~mm}$.

\section{DISCUSSION}

General leaf anatomy of Andropogon gerardii-Studies of grass leaf anatomy have included variation across seasons (Ferris et al., 1996), between perennials and annuals (Garnier and Laurent, 1994), between $\mathrm{C}_{3}$ and $\mathrm{C}_{4}$ species (Dengler et al., 1994), within $\mathrm{C}_{4}$ subtypes (Carmo-Silva et al., 2009), across $\mathrm{C}_{4}$ species (Magai et al., 1994), between species of a single genus (Maricle et al., 2009), and adaptations of species to water stress (Maricle et al., 2007; Hameed et al., 2009). Other studies have compared variation among multiple species along a precipitation gradient (Cunningham et al., 1999), but few studies have addressed variation in leaf anatomy of a single species over a precipitation gradient (Vasellati et al., 2001), as we have done here. Moreover, genetic variations between big bluestem and sand bluestem could represent structural changes during incipient edaphic speciation (Barnes, 1986). In the present study, five populations of $A$. gerardii were planted in common gardens across a precipitation gradient to investigate which anatomical characteristics of leaves are environmentally controlled and which are genetically controlled. All populations of A. gerardii exhibited Kranz anatomy in the "classical" NADP-ME type, with one layer of large bundle sheath cells containing centrifugally arranged chloroplasts (Dengler and Nelson, 1999). Variation in leaf anatomy was due to a combination of drought adaptation of populations and environmental variability of anatomical characteristics.

Drought adaptations-Many grasses are well adapted to xeric environments. Typical adaptations include narrower leaf width (Redmann, 1985) and leaf rolling or folding behavior. Bulliform cells also decrease in volume as turgor pressure and plant water potential decrease (Kadioglu et al., 2012).

Andropogon gerardii has abundant bulliform cells (Magai et al., 1994), and the percentage of the leaf that consists of bulliform cells varied among populations and sites. Although bulliform cells were under considerable environmental control, there 


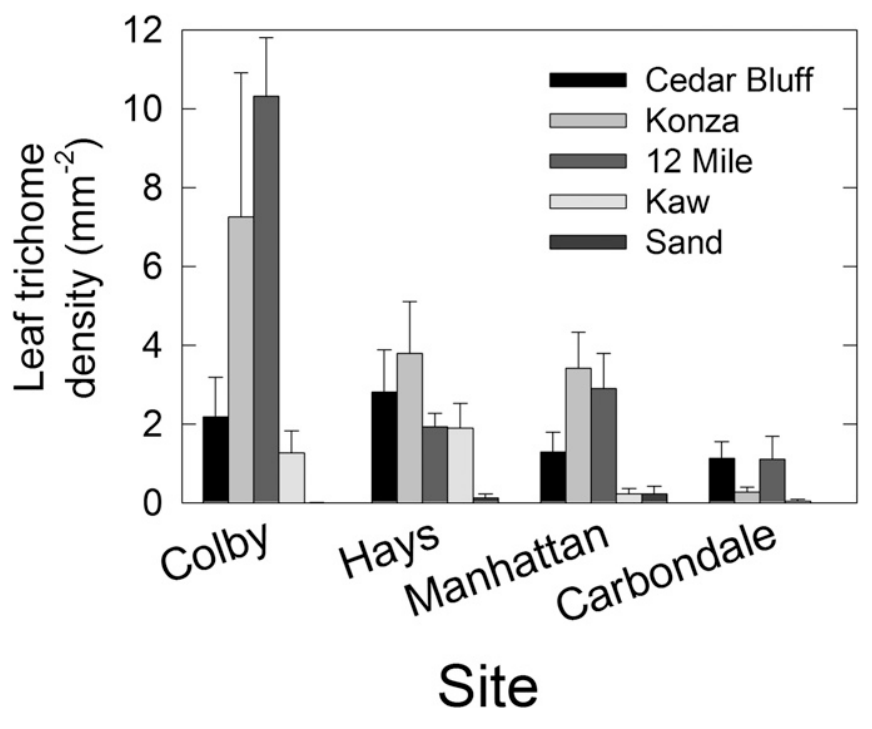

Fig. 7. Trichome density on Andropogon gerardii leaves at the five planting sites. Trichome densities were calculated on the adaxial surface of the basal 10-15 $\mathrm{mm}$ of the lamina. Bars are means of three replicate plants \pm SE.

was also a significant genetic component. Sand bluestem had a lower percentage of bulliform cells compared to big bluestem populations. Previous observations indicate sand bluestem rolls leaves to a greater degree than big bluestem (Barnes, 1985, 1986). Although bulliform cells are involved in leaf rolling, perhaps the proportion of bulliform cells in the leaf does not directly relate to leaf rolling ability in A. gerardii. Placement of bulliform cells in a leaf might be more important than size of individual bulliform cells. The mesic big bluestem populations from 12 Mile and Konza generally had greater proportions of bulliform cells than did the xeric Cedar Bluff population. These findings were contrary to our expectation that the most xeric population, Cedar Bluff, would have the greatest proportion of bulliform cells. Presence of a large proportion of bulliform cells was anticipated to be a drought adaptation to enhance leaf rolling and folding. While having larger and more abundant bulliform cells might allow a leaf to roll more under drought, it requires more water to produce large bulliform cells and maintain their turgor pressure. Furthermore, leaf rolling and folding in grasses might have a limited role in water loss, as stomata typically close prior to leaf rolling or folding during times of water stress (Redmann, 1983).

Studies have indicated grass leaf thickness increases as available moisture decreases (Carmo-Silva et al., 2009; Chen and Wang, 2009; Riaz et al., 2010; Wang et al., 2011) and is considered an adaptation to drought. Chen and Wang (2009) reported leaf thickness of the grass Leymus chinensis (Trin.) Tzvel. was dependent on water availability, but was also influenced by ecotype. In the present study, we found maximum and minimum thicknesses of $A$. gerardii leaves to be influenced by the population of origin and not the planting site. Sand bluestem had thicker leaves than Kaw, supporting sand bluestem as more drought-adapted than some big bluestem populations. This result is consistent with work of Barnes (1986) and J. M. Ravenek et al. (Kansas State University, unpublished manuscript), who measured thicker leaves in sand bluestem compared with big bluestem. Sand bluestem generally grows in sandy soils that have poor water retention (Barnes, 1985). Having a thicker leaf decreases the surface area to volume ratio, decreasing the evaporative surface of the leaf. Thicker leaves often have greater quantities of mesophyll, increasing photosynthetic capabilities at a rate of transpiration similar to an equally sized, thin leaf (Nobel et al., 1975; Sims and Pearcy, 1992). Moreover, in the present study, all plants were grown in bright sunlight and leaves subjected to bright sunlight are expected to be thicker than shaded leaves (Givnish, 1988). Our measures were consistent with sun leaf measures of $A$. gerardii by Knapp and Gilliam (1985).

Big bluestem populations had a greater density of leaf trichomes compared to sand bluestem, consistent with descriptions by Rydberg (1932). Leaves of sand bluestem can also have trichomes (McGregor et al., 1986), but instead typically have glaucous leaves (Rydberg, 1932; McGregor et al., 1986; Shelton, 2012). Sand bluestem has five times more epicuticular wax than big bluestem (Shelton, 2012; J. M. Ravenek et al. Kansas State University, unpublished manuscript), likely an alternative strategy for water conservation in sand bluestem (Barnes, 1986). In the present study, trichome density was influenced by both population and environment. Leaves from the more mesic Konza and 12 Mile populations had significantly more trichomes compared with Cedar Bluff plants, which are adapted to more xeric environments. Consistent with our observations of bulliform cells, drought adaptation in A. gerardii leaves might be primarily based on area of the evaporative surface and less dependent on factors such as leaf rolling (Redmann, 1983) or trichome density. Nonetheless, trichome density increased in A. gerardii with aridity of planting site, indicating trichomes are an environmental response to water availability, potentially to reduce water loss (PérezEstrada et al., 2000) or decrease incoming radiation (Galmés et al., 2007). It is also possible trichomes on $A$. gerardii are an adaptation to herbivore pressure (e.g., Campos et al., 2009; Scoville et al., 2011), which could be more adaptive in the more mesic A. gerardii populations like 12 Mile and Konza.

$\mathrm{C}_{4}$ plants have closely spaced veins, maintaining short diffusive distances for metabolite transfer (McKown and Dengler, 2007). In A. gerardii, the percentage of leaf area consisting of vascular tissue was lower in populations from xeric relative to mesic regions. The area of vascular tissue correlates with leaf size, which often increases with available moisture (Sack et al., 2012). As soils become drier, less water is available to pass through plants and leaves, reducing the need for vascular tissue to transport water. The xeric Cedar Bluff population of $A$. gerardii had marginally less vascular tissue in a cross-sectional area when compared with the mesic 12 Mile population and the cultivar Kaw. Proportion of vascular tissue in $\mathrm{C}_{4}$ leaves is dependent on the size of veins and interveinal distance. It is unlikely $\mathrm{C}_{4}$ plants will change proportion of vascular tissue as a response to drought because veins are already closely spaced. Within $\mathrm{C}_{4}$ grasses, vascular bundles are closely arranged, and there is likely no advantage to decreasing this already short distance. In addition, no differences were detected between populations or sites for interveinal distances or the size of minor veins. The most western of origin and presumably most drought-adapted population, Cedar Bluff, had greater leaf thickness; when paired with equally sized veins and interveinal distances, thicker leaves resulted in a lower proportion of cross-sectional area of vasculature.

Percentage of vascular tissue is an adaptation among populations but was not influenced by environmental variation across sites in this study. By contrast, major vein size was environmentally influenced but did not differ among populations. Consequently, various features of vasculature are important in drought responses of $A$. gerardii, either from genetic or environmental influences. 
Environmentally influenced characteristics-Size of leaf major veins in A. gerardii was controlled by water availability, as the dry site in Hays, KS had smaller veins compared to the mesic site in Carbondale, IL. Major veins generally decreased in size as soil moisture decreased. Sizes of major veins in this study were similar to measures by Knapp and Gilliam (1985), who demonstrated vein cross-sectional area in A. gerardii increased with bright sunlight. The results of the present study indicate veins can also enlarge as moisture availability increases. The largest veins for all populations were in Carbondale, IL, where soil moisture was consistently high (Table 1). Similarly, Frole (2008) noted that the size of xylem vessels of many panicoid grass species increased in size with increasing precipitation. An increase in area of major veins would allow passage of greater volumes of water as it becomes available. However, Barnes (1986) measured the reverse pattern, where size of major veins increased in bluestems grown in sand dunes compared with those grown in meadows. Similarly, Jacobsen et al. (2007) discovered $\mathrm{C}_{3}$ species under high water stress generally had a greater density of xylem, consistent with the relatively large major veins in plants grown in Colby, KS. Plants in Colby had major veins larger than one would expect from a simple precipitation gradient, indicating vascular development in A. gerardii leaves depends on more than soil water content. Increased vein size might be an adaptation to sandy soils, allowing sand bluestem to take up water quickly when available, because sandy soils have poor water retention (Campbell and Norman, 1998). Interactions between soil water potential, soil type, and the resulting plant development could be an interesting area for future research.

Leaf midrib thickness increased across sites as soil moisture increased. Midribs primarily consisted of large, colorless parenchyma cells that were highly vacuolated and likely functioned to store water. Hameed et al. (2012) measured increases in leaf midrib thickness in Panicum antidotale Retz. with increased water availability. Colorless parenchyma cells in A. gerardii leaf midribs might have a functional role. Carmo-Silva et al. (2009) noted leaves of Paspalum dilatum Poir. had prominent midribs, causing folding of leaves rather than rolling. Barnes $(1985,1986)$ noted big bluestem leaves generally fold, whereas sand bluestem leaves roll into cylinders. Thicker midribs of big bluestem compared with sand bluestem might induce leaf folding rather than rolling. Leaves at the mesic Carbondale site had larger colorless parenchyma cells than in the leaves at xeric sites in Colby and Hays, KS. Small cells are adapted to maintain lower water potentials compared with large cells (Cutler et al., 1977), enabling the plant to retain turgor pressure in drier soils. As soil moisture increased, more water was available for cell and leaf expansion. Andropogon gerardii grown in a mesic environment evidently has an increased ability to fold leaves at the midrib. Nevertheless, how leaf thickness in A. gerardii is affected by soil type and moisture remains an open question. In a field experiment, Barnes (1986) measured increased leaf thickness in bluestems grown in sand dunes compared with those grown in meadows. By contrast, in a greenhouse experiment, J. M. Ravenek et al. (Kansas State University, unpublished manuscript) measured lower specific leaf area (thicker leaves) in big bluestem and sand bluestem grown in prairie soil compared to sand. Measurements by Barnes (1986) and Ravenek et al. (unpublished manuscript) are potentially different due to soil type, water availability, and environmental variation between field and greenhouse such as radiation, wind, and humidity during leaf development of $A$. gerardii.
Size of bulliform cells was influenced by the environment. At Manhattan, KS, where rainfall was abundant, bulliform cells were $26 \%$ larger than at Colby, KS where conditions were dry; however, Hays, KS and Carbondale, IL were not different from Colby and Manhattan. The 2010 growing season in Carbondale was drier than average, which might have contributed to the smaller-than-expected area of bulliform cells in leaves at Carbondale. In addition, the large and abundant colorless parenchyma cells in leaf midribs at Carbondale might offset the benefit of large bulliform cells adaxial to minor veins. Leaf folding potentially reduces the need for large bulliform cells.

Measures by Barnes (1986) demonstrated trichome density of big bluestem and sand bluestem was greater in common gardens at meadow sites compared with dune sites. In the present study, trichome density increased as site aridity increased, except in sand bluestem. Leaves of sand bluestem had very few leaf trichomes across sites, as the relevant drought adaptations in sand bluestem are likely due to the glaucous coat on leaves (Barnes, 1986; Shelton, 2012; J. M. Ravenek et al. (Kansas State University, unpublished manuscript)). How leaf wax influences water loss compared with trichomes is highly relevant in drought-adapted grasses like A. gerardii.

Conclusion-Whereas environmental factors are highly influential on leaf anatomy, a genetic predisposition for certain characteristics plays an equal role. Within A. gerardii, clear differences in characteristics were evident between populations. Genetic characteristics in drought-adapted leaves of A. gerardii included a smaller proportion of bulliform cells, a smaller proportion of vascular tissue, fewer trichomes, and thicker leaves compared to leaves of A. gerardii from mesic sites. Environmentally influenced characteristics of droughtadapted leaves included decreased midrib thickness, smaller major veins, and a smaller proportion of bulliform cells within each leaf compared to mesic-adapted leaves. Leaves at xeric sites responded to smaller volumes of water by having small major veins and many trichomes, potentially reducing transpiration.

Leaves adapted to mesic environments had a genetic predisposition toward many large bulliform cells and abundant vascular tissue. In environments with high soil moisture such as Carbondale, leaf midribs were thicker, major veins and bulliform cells were larger, and trichome density was lower than in leaves at sites with lower soil moisture. Leaves at mesic sites had large major veins to increase water transport and thick midribs with abundant colorless parenchyma (water storage) cells. In addition, large bulliform cells were available to increase leaf rolling, potentially reducing water loss when conditions became dry. However, leaves sampled from the driest site in Colby also showed thick midribs and large major and minor veins, indicating that environmental factors in addition to climate influence these traits of leaf anatomy and provide an interesting area for further investigation. Ongoing research at these sites includes experimental drought treatments, which will elucidate the specific role of drought in these features. Nonetheless, the present results indicate many anatomical and morphological features of A. gerardii leaves that are under environmental or genetic influence. This work might provide insights into the ability of the dominant prairie grass to adjust (or not) as conditions become drier in the future (IPCC, 2007; NOAA, 2012). 


\section{LITERATURE CITED}

AXELROD, D. I. 1985. Rise of the grassland biome, central North America. Botanical Review 51: 163-201.

Barkworth, M. E., L. K. Anderton, K. M. Capels, S. Long, and M. B. Piep. 2007. Manual of grasses for North America. Utah State University Press, Logan, Utah, USA.

BARNES, P. W. 1985. Adaptation to water stress in the big bluestem-sand bluestem complex. Ecology 66: 1908-1920.

BARnes, P. W. 1986. Variation in the big bluestem (Andropogon gerardii)-sand bluestem (Andropogon hallii) complex along a local dune meadow gradient in the Nebraska sandhills. American Journal of Botany 73: 172-184.

Bresson, C. C., Y. Vitasse, A. Kremer, and S. Delzon. 2011. To what extent is altitudinal variation of functional traits driven by genetic adaptation in European oak and beech? Tree Physiology 31: $1164-1174$

Brown, R. H., J. H. Bouton, P. T. Evans, H. E. Malter, and L. L. Rigsby. 1985. Photosynthesis, morphology, leaf anatomy, and cytogenetics of hybrids between $\mathrm{C}_{3}$ and $\mathrm{C}_{3} / \mathrm{C}_{4}$ Panicum species. Plant Physiology 77: 653-658

Brown, W. V. 1958. Leaf anatomy in grass systematics. Botanical Gazette 119: 170-178.

BRown, W. V. 1975. Variations in anatomy, associations, and origins of Kranz tissue. American Journal of Botany 62: 395-402.

Campbell, G., AND J. M. Norman. 1998. An introduction to environmental biophysics, 2nd ed. Springer, New York, New York, USA.

Campos, M. L., M. de Almeida, M. L. Rossi, A. P. Martinelli, C. G. Litholdo, A. Figueira, F. T. Rampelotti-Ferreira, et al. 2009. Brassinosteroids interact negatively with jasmonates in the formation of anti-herbivory traits in tomato. Journal of Experimental Botany 60: 4347-4361.

Carmo-Silva, A. E., A. Francisco, S. J. Powers, A. J. Keys, L. Ascensão, M. A. Parry, and M. C. Arrabaça. 2009. Grasses of different $\mathrm{C}_{4}$ subtypes reveal leaf traits related to drought tolerance in their natural habitats: Changes in structure, water potential, and amino acid content. American Journal of Botany 96: 1222-1235.

Chen, K. M., F. Wang, Y. H. Wang, T. Chen, Y. X. Hu, and J. X. Lin. 2006. Anatomical and chemical characteristics of foliar vascular bundles in four reed ecotypes adapted to different habitats. Flora 201: $555-569$.

Chen, L., AND R. WANG. 2009. Anatomical and physiological divergences and compensatory effects in two Leymus chinensis (Poaceae) ecotypes in northeast China. Agriculture, Ecosystems \& Environment 134: 46-52.

Clauden, J. C., D. D. Keck, and W. M. Hiesey. 1948. Experimental studies on the nature of species. III. Environmental responses of climatic races of Achillea. Carnegie Institution of Washington Publication 581: $1-129$.

Cordell, S., G. Goldstein, D. Mueller-Dombois, D. Webb, and P. M. Vitousek. 1998. Physiological and morphological variation in Metrosideros polymorpha, a dominant Hawaiian tree species, along an altitudinal gradient: The role of phenotypic plasticity. Oecologia 113: $188-196$.

Cunningham, S. A., B. Summerhayes, and M. Westoby. 1999. Evolutionary divergences in leaf structure and chemistry, comparing rainfall and soil nutrient gradients. Ecological Monographs 69: 569-588.

Cutler, J. M., D. W. Rains, AND R. S. Loomis. 1977. The importance of cell size in the water relations of plants. Physiologia Plantarum 40: $255-260$.

Dengler, N. G., R. E. Dengler, P. M. Donnelly, and P. W. Hattersley, 1994. Quantitative leaf anatomy of $\mathrm{C}_{3}$ and $\mathrm{C}_{4}$ grasses (Poaceae): Bundle sheath and mesophyll surface area relationships. Annals of Botany 73: 241-255.

Dengler, N. G., And T. Nelson. 1999. Leaf structure and development in $\mathrm{C}_{4}$ plants. In R. F. Sage and R. K. Monson, $\mathrm{C}_{4}$ plant biology, 133-172. Academic Press, San Diego, California, USA.

Epstein, H. E., W. K. Lauenroth, I. C. Burke, and D. P. Coffin. 1998. Regional productivities of plant species in the Great Plains of the United States. Plant Ecology 134: 173-195.
ETtERSON, J. R. 2004. Evolutionary potential of Chamaecrista fasciculata in relation to climate change. I. Clinal patterns of selection along an environmental gradient in the Great Plains. Evolution 58: 1446-1456.

Ferris, R., I. Niss, T. Behaeghe, and I. Impens. 1996. Elevated $\mathrm{CO}_{2}$ and temperature have different effects on leaf anatomy of perennial ryegrass in spring and summer. Annals of Botany 78: 489-497.

Frole, K. M. 2008. Drought responses of $\mathrm{C}_{3}$ and $\mathrm{C}_{4}$ (NADP-ME) panicoid grasses. MS thesis, Rhodes University, Grahamstown, South Africa.

Galmés, J., H. Medrano, and J. Flexas. 2007. Photosynthesis and photoinhibition in response to drought in a pubescent (var. minor) and a glabrous (var. palaui) variety of Digitalis minor. Environmental and Experimental Botany 60: 105-111.

Garnier, E., AND G. LaURent. 1994. Leaf anatomy, specific mass and water content in congeneric annual and perennial grass species. New Phytologist 128: 725-736.

Garnier, E., J. L. SALAGer, G. Laurent, And L. Sonie. 1999. Relationships between photosynthesis, nitrogen and leaf structure in 14 grass species and their dependence on the basis of expression. New Phytologist 143: 119-129.

Givnish, T. J. 1988. Adaptation to sun and shade: A whole-plant perspective. Australian Journal of Plant Physiology 15: 63-92.

Hameed, M., M. Ashraf, and N. Naz. 2009. Anatomical adaptations to salinity in cogon grass [Imperata cylindrica (L.) Raeuschel] from the Salt Range, Pakistan. Plant and Soil 322: 229-238.

Hameed, M., S. Batool, N. Naz, T. Nawaz, and M. Ashraf. 2012. Leaf structural modifications for drought tolerance in some differentially adapted ecotypes of blue panic (Panicum antidotale Retz.). Acta Physiologiae Plantarum 34: 1479-1491.

Hovenden, M. J., AND J. K. V. Schoor. 2004. Nature vs. nurture in the leaf morphology of southern beech, Nothofagus cunninghamii (Nothofagaceae). New Phytologist 161: 585-594.

IPCC. 2007. Climate change 2007: Physical science basis. Contribution of Working Group I to Fourth Assessment Report of International Panel on Climate Change. IPCC, Geneva, Swtizerland.

Jacobsen, A. L., L. Agenbag, K. J. Esler, R. B. Pratt, F. W. Ewers, and S. D. Davis. 2007. Xylem density, biomechanics and anatomical traits correlate with water stress in 17 evergreen shrub species of the Mediterranean-type climate region of South Africa. Journal of Ecology 95: 171-183.

Jiang, C. D., X. Wang, H. Y. Gao, L. Shi, and W. S. Chow. 2011. Systemic regulation of leaf anatomical structure, photosynthetic performance, and high-light tolerance in sorghum. Plant Physiology 155: $1416-1424$.

Kadioglu, A., R. Terzi, N. Saruhan, and A. Saglam. 2012. Current advances in the investigation of leaf rolling caused by biotic and abiotic stress factors. Plant Science 182: 42-48.

Knapp, A. K., J. M. Briggs, J. M. Blair, and C. L. Turner. 1998. Patterns and controls of aboveground net primary production in tallgrass prairie. In A. K. Knapp, J. M. Briggs, D. C. Hartnett, and S. L. Collins [eds.], Grassland dynamics: Long-term ecological research in tallgrass prairie, 193-221. Oxford University Press, New York, New York, USA.

Knapp, A. K., and F. S. Gilliam. 1985. Response of Andropogon gerardii (Poaceae) to fire-induced high vs. low irradiance environments in tallgrass prairie: Leaf structure and photosynthetic pigments. American Journal of Botany 72: 1668-1671.

KöRner, C., P. BANnISTER, AND A. F. Mark. 1986. Altitudinal variation in stomatal conductance, nitrogen content and leaf anatomy in different plant life forms in New Zealand. Oecologia 69: 577-588.

Liu, Y. B., X. R. Li, M. L. Liu, B. CaO, H. J. Tan, J. Wang, and X. J. Li. 2012. Responses of three different ecotypes of reed (Phragmites communis Trin.) to their natural habitats: Leaf surface micro-morphology, anatomy, chloroplast ultrastructure and physio-chemical characteristics. Plant Physiology and Biochemistry 51: 159-167.

Magai, M. M., D. A. Sleper, and P. R. Beuselinck. 1994. Degradation of three warm-season grasses in a prepared cellulase solution. Agronomy Journal 86: 1049-1053.

Maricle, B. R., D. R. Cobos, and C. S. CAmpbell. 2007. Biophysical and morphological leaf adaptations to drought and salinity in salt marsh grasses. Environmental and Experimental Botany 60: 458-467. 
Maricle, B. R., N. K. Koteyeva, E. V. Voznesenskaya, J. R. Thomasson, AND G. E. Edwards. 2009. Diversity in leaf anatomy, and stomatal distribution and conductance, between salt marsh and freshwater species in the $\mathrm{C}_{4}$ genus Spartina (Poaceae). New Phytologist 184: 216-233.

McGregor, W. T., T. M. Barkley, R. E. Brooks, and E. K. Schofield. 1986. Flora of the Great Plains. University Press of Kansas, Lawrence, Kansas, USA.

McKown, A. D., And N. G. Dengler. 2007. Key innovations in the evolution of Kranz anatomy and $\mathrm{C}_{4}$ vein pattern in Flaveria (Asteraceae). American Journal of Botany 94: 382-399.

McMillan, C. 1959 . The role of ecotypic variation in the distribution of the central grassland of North America. Ecological Monographs 29: 285-308.

MCWhorter, C. G. 1971. Growth and development of johnsongrass ecotypes. Weed Science 19: 141-147.

Muhaidat, R., R. F. Sage, and N. G. Dengler. 2007. Diversity of Kranz anatomy and biochemistry in $\mathrm{C}_{4}$ eudicots. American Journal of Botany 94: $362-381$.

Newell, L. C., AND L. V. Peters. 1961. Performance of hybrids between divergent types of big bluestem and sand bluestem in relation to improvement. Crop Science 1: 370-373.

NOAA. 2012. U.S. Drought Monitor [online]. National Drought Mitigation Center, Lincoln Nebraska, USA; U.S. Department of Agriculture, and National Oceanic \& Atmospheric Administration. Available at http://droughtmonitor.unl.edu/[accessed 12 July 2012].

Nobel, P. S., L. J. Zaragoza, And W. K. Smith. 1975. Relation between mesophyll surface area, photosynthetic rate, and illumination level during development for leaves of Plectranthus parviflorus Henckel. Plant Physiology 55: 1067-1070.

Pérez-Estrada, L. B., Z. CAno-Santana, and K. Oyama. 2000. Variation in leaf trichomes of Wigandia urens: Environmental factors and physiological consequences. Tree Physiology 20: 629-632.

Redmann, R. E. 1983. Structural and physiological adaptations in the leaves of xeric grasses. American Journal of Botany 70: 96 [abstract].

Redmann, R. E. 1985. Adaptation of grasses to water stress-leaf rolling and stomate distribution. Annals of the Missouri Botanical Garden 72: 833-842.

Riaz, A., A. Younis, M. Hameed, and S. Kiran. 2010. Morphological and biochemical responses of turf grasses to water deficit conditions. Pakistan Journal of Botany 42: 3441-3448.

RuzIN, S. E. 1999. Plant microtechnique and microscopy. Oxford University Press, New York, New York, USA.

RydberG, A. 1932. Flora of the prairies and plains of Central North America. New York Botanical Garden, Bronx, New York, USA.

Sack, L., C. Scoffoni, A. D. McKown, K. Frole, M. Rawls, J. C. Havran, H. Tran, and T. Tran. 2012. Developmentally based scaling of leaf venation architecture explains global ecological patterns. Nature Communications 3: 837.
Sala, O. E., W. J. Parton, L. A. Joyce, and W. K. Lauenroth. 1988 Primary production of the central grassland region of the United States. Ecology 69: 40-45.

Scheiner, S. M., And C. J. Goodnight. 1984. The comparison of phenotypic plasticity and genetic variation in populations of the grass Danthonia spicata. Evolution 38: 845-855.

Schmid, B., And C. Dolt. 1994. Effects of maternal and paternal environment and genotype on offspring phenotype in Solidago altissima L. Evolution 48: 1525-1549.

Scoville, A. G., L. L. Barnett, S. Bodbyl-Roels, J. K. Kelly, and L. C. Hileman. 2011. Differential regulation of a MYB transcription factor is correlated with transgenerational epigenetic inheritance of trichome density in Mimulus guttatus. New Phytologist 191: 251-263.

Shaw, R. G., AND J. R. EtTERSon. 2012. Rapid climate change and the rate of adaptation: Insight from experimental quantitative genetics. New Phytologist 195: 752-765.

Shelton, J. 2012. Epicuticular wax chemistry, morphology, and physiology in sand bluestem, Andropogon gerardii ssp. hallii, and big bluestem, Andropogon gerardii ssp. gerardii. M.S. thesis, Kansas State University, Manhattan, Kansas, USA.

Sims, D. A., AND R. W. Pearcy. 1992. Response of leaf anatomy and photosynthetic capacity in Alocasia macrorrhiza (Araceae) to a transfer from low to high light. American Journal of Botany 79: 449-455.

Smith, W. K., And P. S. Nobel. 1978. Influence of irradiation, soil water potential, and leaf temperature on leaf morphology of a desert broadleaf, Encelia farinosa Gray (Compositae). American Journal of Botany 65: 429-432.

Stace, C. A. 1991. Plant taxonomy and biosystematics. Cambridge University Press, Cambridge, UK.

Sudderth, E. A., R. M. Muhaidat, A. D. McKown, F. Kocacinar, and R. F. SAGE. 2007. Leaf anatomy, gas exchange and photosynthetic enzyme activity in Flaveria kochiana. Functional Plant Biology 34: 118-129.

Vasellati, V., M. Oesterheld, D. Medan, and J. Loreti. 2001. Effects of flooding and drought on the anatomy of Paspalum dilatatum. Annals of Botany 88: 355-360.

Wang, R., W. Huang, L. Chen, L. Ma, C. Guo, and X. Liu. 2011. Anatomical and physiological plasticity in Leymus chinensis (Poaceae) along large-scale longitudinal gradient in northeast China. PLoS ONE 6: e26209.

Williams, D. G., ANd R. A. Black. 1993. Phenotypic variation in contrasting temperature environments: Growth and photosynthesis in Pennisetum setaceum from different altitudes on Hawaii. Functional Ecology 7: 623-633.

Zheng, W. J., X. P. Zheng, and C. L. Zhang. 2000. A survey of photosynthetic carbon metabolism in 4 ecotypes of Phragmites australis in northwest China: Leaf anatomy, ultrastructure, and activities of ribulose 1,5-bisphosphate carboxylase, phosphoenolpyruvate carboxylase and glycollate oxidase. Physiologia Plantarum 110: 201-208. 